affairs which has been given in this year's PROCEedings has undoubtedly been of great assistance in strengthening the Branch work. The Branches can be further made to feel that they are an integral part of the Institute, if they are asked to assist, as far as possible, in the work of the Institute. They should be represented on committees, and with due regard to the possibility of assembling a working quorum they should be represented on the Board of Directors. Personal visits to the Branches on the part of officers and prominent members would be most helpful in bringing about this feeling of coöperation.

In conclusion we would bring to the attention of the Institute at large, and especially to any members who may have any doubts as to the wisdom of encouraging the Branch work, the fact that this work can be no longer considered as in an experimental or temporary stage. The wisdom of starting the Branch movement is no longer a proper question for debate: the Branches are here with an immense possibility for useful work. It is not conceivable that this work started in the broadest spirit of the greatest good to the entire membership of the Institute can be allowed to languish through a lack of appreciation of its pcssibilities or through a lack of coöperation either on the part of the Branches themselves or on the part of the main body of the Institute.

For the Committee on Local Organizations.

Paul Spencer, Chairman.

\section{Sections and University Branches}

Toledo Section

The regular monthly meeting of Toledo Section, was held August 2, 1907 , at the Boody House. The secretary, Geo. E. Kirk, presided owing to absence of the chairman.

After transacting routine business, Dr. Lee DeForest was introduced.
The address given by Dr. DeForest was most clear and entertaining, accompanied by sketches on the blackboard. The sensitiveness of the arc to electric waves, and the adaptation of this scheme to space or wireless signaling was outlined, followed by references to coherer, polariphone, and other instruments for similar purposes, including the audion.

The general circuits were explained, and the methods of tuning, which may be such as to permit quite a number of stations in overlapping fields without interference. The advantages of the wireless telephone over the wireless telegraph, were compared as the wire telephone to that of wire telegraph.

On invitation of Dr. DeForest, after the meeting the members were given an opportunity to visit the wireless telephone station in the Ohio Building, Toledo, where receiving and transmitting was conducted by those present with a station some two blocks distant in the Nicholas Building. Besides conversing, a phonograph rendered several selections from the Nicholas station, showing the transmission to be most accurate. These stations are to be used in developing the wireless telephone on the great lakes.

The Section adjourned to meet the first Friday in September.

\section{Associates Ilected}

At a regular meeting of the Board of Directors held in the Engineers' Building, 33 West Thirty-ninth street, New York, Friday, August 30, 1907, at $3: 30$ p.m., the following 55 Associates were elected:

Adams, Arthur L., Malden Electric Co.; res., 70 Linden Ave., Malden, Mass.

Barfoed, Svend, Draftsman, F. G. Baum \& Co., 1406 Chronicle Bldg., San Francisco, Cal.

Biegler, Philip Sheridan, Instructor in Electrical Engineering, State University of Iowa, Iowa City, Iowa. 